\title{
Larval density and physicochemical properties of three different breeding habitats of Anopheles mosquitoes in Sudan savannah region of Jigawa State, Nigeria
}

\author{
Asma'u Mahe ${ }^{1,2}$, Adamu Jibril Alhassan ${ }^{1}$, Chimaobi James Ononamadu ${ }^{3}$, \\ Nura Lawal ${ }^{4}$, Sadiya Ahmad Bichi ${ }^{5}$, Sani Ado Haruna ${ }^{6}$, \\ Firdausi Abdulkadir Sani ${ }^{6}$, Abdullahi Abdulkadir Imam ${ }^{1 *}$ \\ ${ }^{1}$ Department of Biochemistry, \\ Faculty of Basic Medical Sciences, \\ Bayero University, Kano, Nigeria. \\ ${ }^{2}$ Department of Biochemistry, \\ Faculty of Science, \\ Federal University, Dutse, \\ Jigawa State, Nigeria.
}

${ }^{3}$ Department of Biochemistry and Forensic Science, Nigeria Police Academy, Wudil, Nigeria.

${ }^{4}$ Department of Biochemistry, Faculty of Science, Federal University, Dutsinma, Katsina State, Nigeria.

${ }^{5}$ Department of Biochemistry, Faculty of Science, Kano University of Science and Technology, Wudil, Kano State, Nigeria.

${ }^{6}$ Department of Biochemistry, Faculty of Science, Yusuf Maitama Sule University, Kano, Kano State, Nigeria.

E-mail: aaimam.bch@buk.edu.ng

\begin{abstract}
Mosquitoes are tiny insects that can serve as vectors for numerous infectious diseases like malaria. Malaria is considered as one of the major causes of mortality, loss of productivity and a major contributor of poverty in the African continent. In 2020, most global malaria cases (94\%) were recorded in the Africa Region. In Nigeria, about $97 \%$ of the estimated populations are at risk of malaria, with up to $27 \%$ and $24 \%$ of Africa and global malaria deaths respectively in 2018. Malaria control programmes in Africa have challenge of rising insecticide resistance in the main anopheline vectors, this affects primary malaria vector control interventions. In Africa, the dominant mosquito species that transmit
\end{abstract}

*Author for Correspondence

A. A. Imam et al, DUJOPAS 7 (4b): 50-59, 2021 
malaria parasites are mainly Anopheles gambiae s.s. A key control strategy against major mosquitoborne diseases involves targeting mosquito vectors to disrupt the transmission of diseases. Environmental changes can alter the genetic structure, protein profiles and enzymes of mosquitoes leading to increase in insecticide resistance. Knowing the ecology, spatial distribution of mosquito larvae, and some environmental features like physicochemical factors are important in tackling insecticide resistance. Water and larval samples were collected from three Anopheles mosquito breeding sites in August, September and October, 2019. Physicochemical parameters, larval densities and morphological specie identifications were determined. Results from this study reveal variation in levels of each studied parameter according to the site of the study. These variations can be attributed to differences in activities that occur in each site of the study.. Correlation studies indicated a significantly higher larval density in agricultural site relative to industrial and residential sites, this was by a magnitude of 10.65 and 41.30 respectively. Anopheles gambiae s.s. complex was found to be predominant in all the three study sites. These physicochemical parameters can either have negative or positive effect on mosquito biology depending on their levels, hence can affect vector control measures making it significant in terms of vector control programmes.

Keywords: Anopheles mosquitoes, Malaria, physicochemical parameters, larval density

\section{INTRODUCTION}

Mosquitoes are tiny insects that belong to Arthropoda, Hexapoda, Insecta, Diptera, Nematocera, and Culicidae, as phylum, superclass, class, order, suborder, and family respectively with subfamilies of Anophelinae, Culicinae, Toxorhynchitinae (Ilahi and Suleman, 2013). These species of mosquitoes serve as vectors for numerous infectious diseases, about 3,500 mosquito species were classified into 41 genera (Kilpatrick, 2011), this feature is relative to their abundance, diversity, vector capacity and recurrent infection (Njabo, 2013). Mosquitoes of Anopheles, Culex and Aedes genera are among the main vector species of protozoan, nematode and virus pathogens (Wilke and Marrelli, 2015). Mosquitoes transmit and vector diseases like malaria, yellow fever, dengue and some other diseases to millions of people annually (Noutchamae and Anumudu, 2009). In Africa, the dominant mosquito species that transmit malaria parasites are mainly Anopheles gambiae s.s. complex and Anopheles funestus. These species are widely spread over tropical and subtropical Africa (Coetzee et al., 2013).

Malaria is one of the major causes of mortality, and loss of productivity in the African region. It can also result in strong negative effect on developmental stages in children that can lead to permanent disability to many that survive the disease (Knox et al., 2014). Malaria is considered as a major contributor of poverty in Africa (Okorosobo et al., 2011). About 228 and 229 million malaria cases were globally recorded in 2018 and 2019 respectively. Most of these cases (94\%) were recorded in the Africa Region (WHO, 2021). In Nigeria, about 97\% of the estimated populations are at risk of malaria, with up to $27 \%$ and $24 \%$ of Africa and global malaria deaths respectively (WHO, 2019). Six countries are responsible for more than half of all the global malaria cases, these countries include; Nigeria, Democratic Republic of Congo and Uganda with $25 \%, 12 \%$ and $5 \%$ of the global cases respectively (WHO, 2019). Malaria control programs in Africa have challenge of rising insecticide resistance in the main anopheline vectors, thus, affecting primary malaria vector control interventions (Knox et al., 2014).

A key control strategy against major mosquito- borne diseases involves targeting mosquito vectors to disrupt the transmission of diseases (Niyang et al., 2018). Long-term use of agrochemicals in agricultural practices alter the natural environment thereby leading to the selection of resistance in insect species (WHO, 2013; Alhassan et al., 2015). Knowing the ecology and spatial distribution of mosquito larvae is significant in the effectiveness of vector control measures (Mereta et al., 2013). Breeding site water parameters such as: $\mathrm{pH}$, 
temperature, ammonia, phosphate, sulphate, nitrate, nitrite, chloride, calcium e.t.c affect larval density of mosquitoes. Changes in these parameters of the breeding sites might result in positive or negative effects to the vectors. Temperature below $14^{\circ} \mathrm{C}$ and above $30^{\circ} \mathrm{C}$ decrease larval growth rate in most vector specie. Many mosquito larvae are naturally found in $\mathrm{pH} 3.3-10.5$, dissolved nitrogen content can negatively affect larval growth of some vectors (Liu et al., 2012; Nikookar et al., 2017). Environmental temperature changes can alter the genetic structure, protein profiles and enzymes of mosquitoes leading to increase in resistance (Soko et al., 2015). Proper understanding of the nature of resistance is important in the management and control of malaria vectors (Nkya et al., 2014). Monitoring and knowledge of environmental factors like physicochemical parameters are important in tackling insecticide resistance challenges (Ononamadu et al., 2020). Liu et al., 2012, Mereta et al., 2013, and Nikookar et al., 2017 studied physico-chemical characteristics of anopheline mosquito larval breeding habitats elsewhere as implications for control of malaria. Alhassan et al., 2015, Safiyanu et al., 2016, Safiyanu et al., 2017, Safiyanu et al., 2019 and Ononamadu et al., 2020 reported insecticide resistance in Anopheles mosquitoes from areas of the same region as that of this study. Reports on the larval density and physicochemical parameters of mosquitoes' breeding sites of this study area is lacking. Hence the need to study these parameters of Anopheles mosquitoes' breeding sites of the study area.

\section{MATERIALS AND METHOD}

\section{Study Area}

The study was carried out in Sudan savannah region of Jigawa State. Three sites were studied; (1) Agricultural and (2) Industrial sites from Hadejia town (Latitude: $12^{\circ} 44^{\prime} 98^{\prime \prime} \mathrm{N}$, Longitude: $10^{\circ} 04^{\prime} 44^{\prime \prime} \mathrm{E}$ ) while (3) Residential site from Dutse town (Latitude: $11^{\circ} 75^{\prime} 62^{\prime \prime} \mathrm{N}$, Longitude: $\left.9^{\circ} 33^{\prime} 90^{\prime \prime} \mathrm{E}\right)$. The State has a total land area of approximately $22,410 \mathrm{~km}^{2}$ and a density of 251.7 per $\mathrm{km}^{2}$. It has coordinates of: $12000^{1} \mathrm{~N} 9045^{1} \mathrm{E}$ between latitudes $11.00^{0} \mathrm{~N}$ to $13.00^{0} \mathrm{~N}$ and longitudes $8.00^{\circ} \mathrm{E}$ to $10.15^{\circ} \mathrm{E}$ (JGS, 2015). Occupation include: fishing, rice farming and establishment of irrigation based activities.

\section{Sample Collection}

Breeding sites water samples and Anopheles mosquito larvae were collected from randomly selected vegetation farms, chocked gutters, water logged, marshy or swampy areas around each study site during rainy season (August, September and October, 2019). These sampling sites were found highly polluted with organic materials.

A dipper was used to obtain Anopheles larvae after screening for the presence of the larvae. Anopheles larvae were transferred along with breeding waters to the holding containers before searching for more. This procedure was done over and over until significant numbers of larvae were obtained for each period of the study. This procedure was done according to Robert et al., (2002).

\section{Parameters Determination}

Twenty- seven (27) parameters were determined from mosquitoes' breeding site water samples obtained from the three study sites. These parameters were: $\mathrm{pH}$, temperature, electrical conductivity (EC), turbidity, total dissolved solids (TDS), total suspended solids (TSS), dissolved oxygen (DO), carbonates, bicarbonates, ammonium, nitrates, phosphates, sulphates, nitrites, chlorides, potassium, sodium, calcium, magnesium, zinc, iron, copper, nickel, cobalt, lead, manganese, cadmium. They gave an insight to the kind of activities performed in the study sites. 
DO (dissolved oxygen) was determined using portable DO meter in the laboratory after calibration. The probe was calibrated before use and distilled water was used to rinse the probe each time of use to avoid cross contamination. Total Suspended Solids (TSS) and Total Dissolved Solids (TDS) were done according to APHA (1985).

\section{Physical analysis}

Physical parameters including: $\mathrm{pH}$, temperature, and electrical conductivity were determined by a portable multi-function water quality checker (Model Number: EZ- 9908) at each sampling site and the results were recorded.

\section{Mineral elements Determination}

Sulphate and nitrate were determined according to the method of APHA (1985). Chloride, bicarbonate and carbonate were measured using method of Trivedi and Goel (1986). For determination of the following: phosphate, potassium, magnesium, zinc, nickel, cadmium, iron and manganese, standard methods were used as described by American Public Health Association (APHA, 2005). Copper, cobalt, and lead content of the breeding site water samples were measured by atomic absorption spectrophotometry (AAS). Sodium and calcium were determined by flame photometry.

Digestion of water sample: Water samples were prepared (digested) prior to analysis. $100 \mathrm{ml}$ of well mixed water sample was transferred into a clean beaker; $5 \mathrm{ml}$ of conc. $\mathrm{HNO}_{3}$ was added and slowly heated to boil on a hot plate. It was then allowed to cool and another $5 \mathrm{ml}$ of conc. $\mathrm{HNO}_{3}$ was added. The beaker was covered with a watch glass and returned to the hot plate. A gentle refluxing action of the solution was set by increasing the temperature of the hot plate. Heating was continued with addition of acid as required until digestion was completed. About $1.2 \mathrm{ml}$ conc. $\mathrm{HNO}_{3}$ was added to dissolve the residue. The residue was washed with distilled water and filtered to remove silicate and other insoluble material. The volume of the solution was adjusted to $100 \mathrm{ml}$ in a volumetric flask. A reagent blank determination was carried out. The digested solution was transferred to plastic bottles labelled accurately and were used for mineral determination (AAS and flame photometry).

\section{Specie Identification (Morphological Species identification)}

Anopheles mosquito larvae were identified based on spatial projections on the water surface being horizontally based. Morphological identification was performed according to the keys of (Gillies and Coetzee, 1987). Characteristics unique to all Anopheles mosquitoes were screened using a Zeiss $\times 10$ light microscope.

\section{Statistical Analysis}

Larval density and physicochemical parameters were expressed as mean \pm standard deviation and were analyzed by one-way ANOVA using SPSS Version 20 for comparison of variations between the sampling sites with $p$ value $<0.05$ as significant. Pearson correlation, Linear (multiple) regression and ANOVA were used to study the relationship between larval densities and physicochemical properties, between larval densities and study sites.

\section{RESULTS}

Table 1 gives the physicochemical parameters and larval densities of water from agricultural, industrial and residential breeding sites of Anopheles specie in Hadejia and Dutse. Results from the table indicate varying levels of the assayed parameters in the study sites. Some of the observed variations in the parameters were found to be statistically significant. 
Table 1: Physicochemical parameters and larval densities of Anopheles mosquitoes' breeding sites water samples from Agricultural, Industrial and Residential sites of Hadejia and Dutse

\begin{tabular}{|c|c|c|c|c|c|c|c|c|}
\hline SITES & $\mathrm{pH}$ & $\begin{array}{l}\text { TEMP } \\
\left({ }^{\circ} \mathrm{C}\right)\end{array}$ & $\begin{array}{l}\text { EC } \\
(\mu S / \mathrm{cm})\end{array}$ & $\begin{array}{l}\text { TURB. } \\
\text { (NTU) }\end{array}$ & $\begin{array}{l}\text { TDS } \\
(\mathrm{mg} / \mathrm{L})\end{array}$ & TSS (mg/L) & $\begin{array}{l}\mathrm{DO} \\
(\mathrm{mg} / \mathrm{L} \\
)\end{array}$ & $\begin{array}{l}\text { Larval } \\
\text { density/ } \\
\text { L }\end{array}$ \\
\hline $\begin{array}{l}\text { Agricultural } \\
\text { site }\end{array}$ & $\begin{array}{l}7.77 \pm \\
0.7 a\end{array}$ & $\begin{array}{l}28.57 \pm \\
1.1 \mathrm{a}\end{array}$ & $\begin{array}{l}223.00 \pm \\
65 a\end{array}$ & $\begin{array}{l}30.00 \pm \\
3.0 \mathrm{a}\end{array}$ & $\begin{array}{l}119.26 \pm \\
3.9 a\end{array}$ & $0.12 \pm 0.0 \mathrm{a}$ & $\begin{array}{l}4.76 \pm \\
0.7 a\end{array}$ & $\begin{array}{l}73.33 \pm \\
1.5 \mathrm{a}\end{array}$ \\
\hline $\begin{array}{l}\text { Industrial } \\
\text { site }\end{array}$ & $\begin{array}{l}6.18 \pm \\
0.3 b\end{array}$ & $\begin{array}{l}30.13 \pm \\
1.1 \mathrm{a}\end{array}$ & $\begin{array}{l}216.00 \pm \\
53 a\end{array}$ & $\begin{array}{l}62.20 \pm \\
5.3 b\end{array}$ & $\begin{array}{l}62.23 \pm \\
4.4 \mathrm{~b}\end{array}$ & $0.28 \pm 0.0 \mathrm{a}$ & $\begin{array}{l}4.06 \pm \\
0.5 a\end{array}$ & $\begin{array}{l}62.67 \pm \\
2.0 \mathrm{~b}\end{array}$ \\
\hline $\begin{array}{l}\text { Residential } \\
\text { site }\end{array}$ & $\begin{array}{l}8.60 \pm \\
0.5 a\end{array}$ & $\begin{array}{l}25.00 \pm \\
1.5 b\end{array}$ & $\begin{array}{l}253.00 \pm \\
83 a\end{array}$ & $\begin{array}{l}14.80 \pm \\
1.8 \mathrm{c}\end{array}$ & $\begin{array}{l}102.06 \pm \\
3.7 \mathrm{a}\end{array}$ & $0.05 \pm 0.0 \mathrm{a}$ & $\begin{array}{l}5.00 \pm \\
0.8 \mathrm{a}\end{array}$ & $\begin{array}{l}32.00 \pm \\
2.6 c\end{array}$ \\
\hline
\end{tabular}

EC- Electrical Conductivity, TURB.- Turbidity, TDS- Total Dissolved Solid, TSS- Total Suspended Solid, DODissolved Oxygen. Values were expressed as mean \pm standard deviation. Statistical difference, $(p<0.05)$ using ANOVA and Turkey's HSD test, SPSS version 20. Superscripts: values bearing different letters down a column (across the sites) are statistically different $(\mathrm{p}<0.05)$.

Table 2 indicates differences in levels of chemical parameters of water sample from agricultural, industrial and residential breeding sites of Anopheles specie in Hadejia and Dutse towns. Carbonate, ammonium, nitrate, phosphates, and sulphates varied significantly in agricultural site compared to industrial and residential sites.

Table 2: Chemical parameters of Anopheles mosquitoes' breeding sites water samples from Agricultural, Industrial and Residential sites of Hadejia and Dutse

\begin{tabular}{|c|c|c|c|c|c|c|c|}
\hline SITES & $\begin{array}{l}\mathrm{CO}_{3}^{-} \\
(\mathrm{mg} / \mathrm{L})\end{array}$ & $\begin{array}{l}\mathrm{HCO}_{3} \\
(\mathrm{mg} / \mathrm{L})\end{array}$ & $\begin{array}{l}\mathrm{NH}_{4}^{-} \\
(\mathrm{mg} / \mathrm{L})\end{array}$ & $\begin{array}{l}\mathrm{NO}_{3}^{-} \\
(\mathrm{mg} / \mathrm{L})\end{array}$ & $\begin{array}{l}\mathrm{PO}_{4}^{3-} \\
(\mathrm{mg} / \mathrm{L})\end{array}$ & $\begin{array}{l}\mathrm{SO}_{4}^{2-} \\
(\mathrm{mg} / \mathrm{L})\end{array}$ & $\begin{array}{l}\mathrm{NO}_{2}^{-} \\
(\mathrm{mg} / \mathrm{L})\end{array}$ \\
\hline Agricultural & $\begin{array}{l}28.02 \pm \\
4.8 \mathrm{a}\end{array}$ & $\begin{array}{l}50.16 \pm \\
6.2 a\end{array}$ & $3.17 \pm 0.3 a$ & $\begin{array}{l}11.55 \pm \\
0.9 a\end{array}$ & $\begin{array}{l}98.20 \pm \\
1.5 \mathrm{a}\end{array}$ & $\begin{array}{l}218.74 \pm \\
3.8 \mathrm{a}\end{array}$ & $3.21 \pm 0.1 \mathrm{a}$ \\
\hline Industrial & $\begin{array}{l}32.46 \pm \\
3.8 \mathrm{~b}\end{array}$ & $\begin{array}{l}50.27 \pm \\
5.9 a\end{array}$ & $4.04 \pm 0.1 b$ & $\begin{array}{l}14.70 \pm \\
0.5 b\end{array}$ & $\begin{array}{l}148.64 \pm \\
5.0 \mathrm{~b}\end{array}$ & $\begin{array}{l}317.64 \pm \\
7.0 \mathrm{~b}\end{array}$ & $4.05 \pm 0.4 a$ \\
\hline Residential & $\begin{array}{l}30.53 \pm \\
2.5 b\end{array}$ & $\begin{array}{l}50.68 \pm \\
4.1 \mathrm{a}\end{array}$ & $3.91 \pm 0.2 b$ & $\begin{array}{l}14.22 \pm \\
0.8 b\end{array}$ & $\begin{array}{l}122.79 \pm \\
2.6 c\end{array}$ & $\begin{array}{l}279.64 \pm \\
3.2 b\end{array}$ & $3.97 \pm 0.5 a$ \\
\hline
\end{tabular}

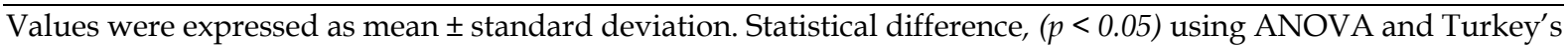
HSD test, SPSS version 20. Superscripts: values bearing different letters down a column (across the sites) are statistically different $(\mathrm{p}<0.05)$

Table 3 shows elemental parameters of water from Agricultural, Industrial and Residential breeding sites of Anopheles specie in Hadejia and Dutse towns. Results gave differences with some elements; chloride, sodium, calcium and magnesium differing significantly agricultural site compared to industrial and residential sites.

Table 3: Elemental parameters of Anopheles mosquitoes' breeding sites water samples from Agricultural, Industrial and Residential sites of Hadejia and Dutse

\begin{tabular}{|c|c|c|c|c|c|c|c|c|c|c|c|c|}
\hline $\begin{array}{l}\mathrm{Cl}^{-} \\
(\mathrm{mg} / \mathrm{L})\end{array}$ & $\begin{array}{l}\mathrm{K}^{+} \\
(\mathrm{mg} / \mathrm{L})\end{array}$ & $\begin{array}{l}\mathrm{Na}^{+} \\
(\mathrm{mg} / \mathrm{L})\end{array}$ & $\begin{array}{l}\mathrm{Ca}^{2+} \\
(\mathrm{mg} / \mathrm{L})\end{array}$ & $\begin{array}{l}\mathrm{Mg}^{2+} \\
(\mathrm{mg} / \mathrm{L})\end{array}$ & $\begin{array}{l}\mathrm{Zn}^{2+} \\
(\mathrm{mg} / \mathrm{L})\end{array}$ & $\begin{array}{l}\mathrm{Fe}^{2+} \\
(\mathrm{mg} / \mathrm{L})\end{array}$ & $\begin{array}{l}\mathrm{Cu}^{2+} \\
(\mathrm{mg} / \mathrm{L})\end{array}$ & $\begin{array}{l}\mathrm{Ni}^{2+} \\
(\mathrm{mg} / \mathrm{L})\end{array}$ & $\begin{array}{l}\mathrm{Co}^{2+} \\
(\mathrm{mg} / \mathrm{L})\end{array}$ & $\begin{array}{l}\mathrm{Pb}^{2+} \\
(\mathrm{mg} / \mathrm{L})\end{array}$ & $\begin{array}{l}\mathrm{Mn}^{2+} \\
(\mathrm{mg} / \mathrm{L})\end{array}$ & $\begin{array}{l}\mathrm{Cd}^{2+} \\
(\mathrm{mg} / \mathrm{L})\end{array}$ \\
\hline
\end{tabular}




\begin{tabular}{|c|c|c|c|c|c|c|c|c|c|c|c|c|c|}
\hline Agricultural & $\begin{array}{l}29.66 \pm \\
1.1 \mathrm{a}\end{array}$ & $\begin{array}{l}9.04 \pm \\
1.6 \mathrm{a}\end{array}$ & $\begin{array}{l}20.17 \\
\pm 10.7 a\end{array}$ & $\begin{array}{l}26.04 \\
\pm 3.5 a\end{array}$ & $\begin{array}{l}3.80 \pm \\
0.7 \mathrm{a}\end{array}$ & $\begin{array}{l}0.06 \pm \\
0.0 \mathrm{a}\end{array}$ & $\begin{array}{l}0.03 \pm \\
0.0 \mathrm{a}\end{array}$ & $\begin{array}{l}0.004 \pm \\
0.0 \mathrm{a}\end{array}$ & $\begin{array}{l}0.004 \pm \\
0.0 \mathrm{a}\end{array}$ & $\begin{array}{l}0.020 \pm \\
0.0 \mathrm{a}\end{array}$ & $\begin{array}{l}0.007 \pm \\
0.0 \mathrm{a}\end{array}$ & $\begin{array}{l}0.002 \pm \\
0.0 \mathrm{a}\end{array}$ & $\begin{array}{l}0.237 \pm \\
0.0 \mathrm{a}\end{array}$ \\
\hline Industrial & $\begin{array}{l}34.90 \pm \\
1.6 b\end{array}$ & $\begin{array}{l}11.07 \pm \\
2.4 \mathrm{a}\end{array}$ & $\begin{array}{l}8.47 \\
\pm 3.8 b\end{array}$ & $\begin{array}{l}15.80 \pm \\
1.4 b\end{array}$ & $\begin{array}{l}1.81 \pm \\
1.2 \mathrm{~b}\end{array}$ & $\begin{array}{l}0.06 \pm \\
0.0 \mathrm{a}\end{array}$ & $\begin{array}{l}0.09 \pm \\
0.1 \mathrm{a}\end{array}$ & $\begin{array}{l}0.004 \pm \\
0.0 \mathrm{a}\end{array}$ & $\begin{array}{l}0.004 \pm \\
0.0 \mathrm{a}\end{array}$ & $\begin{array}{l}0.020 \pm \\
0.0 \mathrm{a}\end{array}$ & $\begin{array}{l}0.007 \pm \\
0.0 \mathrm{a}\end{array}$ & $\begin{array}{l}0.001 \pm \\
0.0 \mathrm{a}\end{array}$ & $\begin{array}{l}0.210 \pm \\
0.0 \mathrm{a}\end{array}$ \\
\hline Residential & $\begin{array}{l}35.93 \pm \\
1.6 b\end{array}$ & $\begin{array}{l}10.94 \pm \\
2.5 a\end{array}$ & $\begin{array}{l}12.50 \pm \\
7.7 b\end{array}$ & $\begin{array}{l}41.40 \pm \\
5.4 \mathrm{c}\end{array}$ & $\begin{array}{l}2.34 \pm \\
1.3 b\end{array}$ & $\begin{array}{l}0.06 \pm \\
0.0 \mathrm{a}\end{array}$ & $\begin{array}{l}0.01 \pm \\
0.0 \mathrm{a}\end{array}$ & $\begin{array}{l}0.012 \pm \\
0.0 \mathrm{a}\end{array}$ & $\begin{array}{l}0.003 \\
\pm 0.0 \mathrm{a}\end{array}$ & $\begin{array}{l}0.020 \pm \\
0.0 \mathrm{a}\end{array}$ & $\begin{array}{l}0.007 \pm \\
0.0 \mathrm{a}\end{array}$ & $\begin{array}{l}0.00 \pm \\
0.0 \mathrm{a}\end{array}$ & $\begin{array}{l}0.301 \pm \\
0.0 b\end{array}$ \\
\hline
\end{tabular}

Values were expressed as mean \pm standard deviation. Statistical difference, $(p<0.05)$ using ANOVA and Turkey's HSD test, SPSS version 20. Superscripts: values bearing different letters down a column (across the sites) are statistically different $(\mathrm{p}<0.05)$

Table 4 and 5 show correlation studies between Anopheles mosquito larval densities with some of their breeding sites' physicochemical parameters and correlation between Anopheles mosquito larval densities and the three study sites respectively. Table 5 also indicated that moving from agricultural site to either industrial or residential sites is associated with a decrease in larval density by a magnitude of 10.65 and 41.30 respectively.

Table 4: Correlation between Anopheles mosquito larval densities and some physicochemical parameters of their breeding sites

\begin{tabular}{llcl}
\hline Larval density & $\begin{array}{l}\text { Correlation } \\
\text { Coefficient }\end{array}$ & t- value & p- value \\
\hline Cadmium $(\mathrm{mg} / \mathrm{L})$ & 8.65 & 0.40 & 0.69 \\
Calcium $(\mathrm{mg} / \mathrm{L})$ & -0.06 & 1.32 & 0.19 \\
& & & 0.00
\end{tabular}

Table 5: Correlation between Anopheles mosquito larval densities and the three breeding study sites

\begin{tabular}{llll}
\hline Sites & $\begin{array}{l}\text { Mean } \pm \text { Standard } \\
\text { Deviation }\end{array}$ & $\begin{array}{l}\text { Correlation } \\
\text { Coefficient }\end{array}$ & p- value \\
\hline Agricultural & $73.35 \pm 1.30^{\mathrm{a}}$ & Ref & - \\
Industrial & $62.70 \pm 1.78^{\mathrm{b}}$ & -10.65 & 0.00 \\
& & & 0.00 \\
\hline
\end{tabular}

Table 6 is on specie composition of reared adult Anopheles mosquitoes from the three study sites in Sudan Savannah, Northwestern Nigeria based on morphological specie identification. The table shows abundance of An. gambiae s.s complex in the three study sites. 
Table 6: Specie composition of adult Anopheles mosquitoes based on morphological specie identification from the three study sites in Sudan Savannah, Northwestern Nigeria

\begin{tabular}{llc}
\hline Study Sites & \multicolumn{1}{c}{ Anopheles Species } \\
\hline & An. gambiae s.s complex & An. pharoensis \\
Agricultural & $100 \%$ & - \\
Industrial & $100 \%$ & - \\
Residential & $96 \%$ & $4 \%$ \\
\hline
\end{tabular}

\section{DISCUSSION}

This study was carried out in three distinct sites namely: agricultural, industrial and residential sites in Sudan savannah region of Jigawa State. Hadejia town was taken for agricultural and industrial sites while Dutse town for residential site. Table 1 showed physicochemical parameters and larval densities of breeding sites water samples from the three study sites. The $\mathrm{pH}$ of industrial mosquitoes' breeding site was found to be significantly lower than that of agricultural and residential sites. Temperature variations was also observed, the temperature of residential was significantly lower than the temperatures of the other two sites. These findings can be attributed to differences in the kind of activities occurring in the various study sites. Turbidity, Total dissolved solids (TDS), larval density also varies significantly between the study sites while electrical conductivity (EC), total suspended solids (TSS) and dissolved oxygen (DO) varies non significantly between the breeding sites. Nikookar et al., (2017) reported the significance of breeding site water parameters in development and oviposition of mosquitoes. They also reported that changes in the parameters in larval breeding sites can affect mosquito biology positively or negatively. These parameters can be used as source of energy that help in growth of micro- organisms that serve as food for larvae and also help in oviposition and egg hatching (Kibuthu et al., 2016). Table 2 showed significantly lower carbonate, ammonium, nitrate, phosphate, and sulphate in agricultural site compared to industrial and residential mosquito breeding sites. Table 3 gave the elemental parameters of water from the three breeding sites of Anopheles mosquitoes indicating varying levels of each studied element depending on the site of the study, these variations can also be attributed to differences in activities that occur in each site of the study. Ononamadu et al. (2020) reported significantly higher levels of some physicochemical parameters determined in industrial area compared to residential area of their study. Environmental factors due to human activities could be a key factor in conferring resistance in malaria vector (Alhassan et al., 2015).

Table 4 presented correlation between Anopheles mosquito larval density and some of their breeding sites' physicochemical parameters, parameters that gave significant and high correlation coefficient were presented in the table. The table showed an inverse relationship between calcium level and larval density while increase in nitrite and cadmium levels are directly associated with increase in larval density. A statistically significant relationship exists between nitrite and larval density. Table 5 gave correlation between Anopheles mosquito larval density and the three study sites. The table indicated a significantly higher larval density in agricultural site relative to industrial and residential sites. It also indicated that moving from agricultural site to either industrial or residential sites is associated with decrease in larval density by a magnitude of 10.65 or 41.30 respectively. Larval conditions specifically larval density was reported to have both genotypic and phenotypic effects on some vector populations (Grossman et al., 2018). Variations in levels of physicochemical parameters can have direct implications to vector control. These parameters can either have negative or positive effect on mosquito biology depending on their levels, hence can affect vector control measures. Detail of larval density and physicochemical parameters can help to 
predict changes in case of environmental modifications due to either natural or artificial causes (Nikookar et al., 2017).

Specie composition of adult Anopheles mosquitoes from the three study sites based on morphological specie identification was given in Table 6. Agricultural and industrial sites had $100 \%$ of Anopheles gambiae s.s complex while residential site had $96 \%$ as Anopheles gambiae s.s complex with $4 \%$ as Anopheles pharoensis which are secondary vectors of malaria. The dominant mosquito species in Africa that transmit malaria parasites are mainly Anopheles gambiae s.s. complex and Anopheles funestus, these species are widely spread over tropical and subtropical Africa (Coetzee et al., 2013). This finding of abundance of a primary malaria vector in the three study areas can lead to increase in malaria infection in that area.

\section{CONCLUSION}

This study revealed variations in levels of physicochemical parameters and larval densities in the three studied sites: agricultural, industrial and residential breeding sites. Correlation studies indicated a statistically significant direct proportional relationship between nitrite and larval density, significantly higher larval density was observed in agricultural site relative to industrial and residential sites by a magnitude of 10.65 and 41.30 respectively. Also, one of the dominant mosquito species in Africa that transmit malaria parasites (Anopheles gambiae s.s. complex) was found to be predominant in all the three study sites, these findings are significant in vector control programmes.

Findings from this study can serve as an alarm to vector control programme of the study area because the study showed possible adaptation of Anopheles mosquitoes to their highly polluted breeding sites created by various human activities occurring in the breeding sites coupled with predominance of Anopheles gambiae s.s. complex in the area. These could result in high prevalence of malaria as a result of abundance of malaria vectors.

Current study provides baseline data and is regarded preliminary. It is recommended that more studies in the area should be done considering other parameters like; insecticide residue levels, residual hydrocarbons, chlorophyll, bacterial composition etc.

\section{REFERENCES}

Alhassan, A. J., Sule, M. S., Dangambo M.A, Yayo, A. M., Safiyanu, M. and Sulaiman, D. (2015). Detoxification enzymes activities in DDT and bendiocarb resistant andsuceptible malarial vector (Anophelesgambiae) breed in Auyo residential and irrigation sites Northwest Nigeria. European Scientific Journal. 11(9): 315- 326. ISSN: 1857 - 7881 (Print) e - ISSN 1857- 7431

APHA (1985). Health Association, Washington, DC. Standard Methods for Examination of Water and Wastewater. 16 ${ }^{\text {th }}$ American Public

APHA (2005) American Public Health Association. Standard Methods for the Examination of Water and Wastewater. 21st ed. Washington, DC: American Public Health Association.

Chirebvu, E., and Chimbari, M.J. (2015). Characteristics of Anopheles arabiensis larval habitats

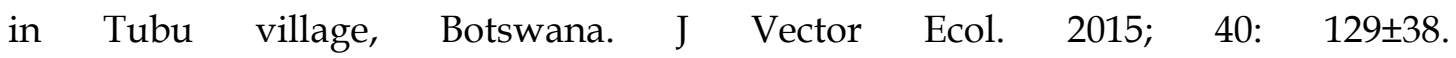
https:/ / doi.org/10.1111/jvec.12141 PMID: 26047193 
Coetzee, M., Hunt, R.H., Wilkerson, R., della Torre, A., Coulibaly, M.B., and Besansky, N.J. (2013). Anopheles coluzzii and Anopheles amharicus, new members of theAnopheles gambiae complex. Zootaxa, 3619:246-274.

Gillies, M.T., and Coetzee, M. (1987). A supplement to the Anophelinae of Africa south of the Sahara (Afrotropical region), Volume 55. South African Institute for medical research: Johannesburg.

Grossman, M.K., Uc-Puc, V., Flores, A.E., Manrique-Saide, P.C., and VazquezProkopec, G.M. (2018). Larval density mediates knockdown resistance to pyrethroid insecticides in adult Aedes aegypti. Parasites \& Vectors (2018) 11:282 https:/ / doi.org/10.1186/s13071-018-2865-x

Ilahi, I., and Suleman, M. (2013). Species composition and relative abundance of mosquitoes in Swat, Pakistan. Int J Innov App Stud. 2013; 2(4):454-463.

Jigawa State (JGS, 2015). A Now World. [http://www.jigawastate.gov.ng/contentpage.php?id=82].

Kibuthu, T.W., Njenga, S.M., Mbugua, A.K., and Muturi, E.J. (2016). Agricultural chemicals: life changer for mosquito vectors in agricultural landscapes? Parasites $\mathcal{E}$ Vectors. 2016; 9: 500. https:// doi.org/10.1186/s13071-016- 1788-7 PMID: 27624456

Kilpatrick, A. M. (2011). Globalization land use and the invasion of West Nile virus. J Sci.; 334(6054):323-327.

Knox, T. B., Juma, E. O., Ochomo, E. O, Jamet, H. P., Ndungo, L., Chege, P. (2014). An online tool for mapping insecticide resistance in major Anopheles vectors of human malaria parasites and review of resistance status for the Afrotropical region.Parasites $\mathcal{E}$ Vectors, 7:76 http:/ / www.parasitesandvectors.com/content/7/1/76

Liu, X.B., Liu, Q.Y., Guo, Y.H., Jiang, J.Y., Ren, D.S., and Zhou, G.C. (2012). Random repeated cross sectional study on breeding site characterization of Anopheles sinensis larvae in distinct villages of Yongcheng City, People's Republic of China. Parasit Vectors. 2012; 5:58. https://doi.org/10.1186/1756-3305-5-58 PMID: 22444032

Mereta, S.T., Yewhalaw, D., Boets, P., Ahmed, A., Duchateau, L., Speybroeck, N., Vanwambeke, S.O., Legesse, W., Meester, L and Goethals, P.L.M. (2013). Physicochemical and biological characterization of anopheline mosquito larval habitats (Diptera: Culicidae): implications for malaria control. Parasites \& Vectors 2013, 6:320 http://www.parasitesandvectors.com/content/6/1/320

Nikookar, S.H., Fazeli-Dinan, M., Azari- Hamidian, S., Mousavinasab, S.N., Aarabi, M., Ziapour, S.P. (2017) Correlation between mosquito larval density and their habitat physicochemical characteristics in Mazandaran Province, northern Iran. PLoS Negl Trop Dis 11(8): e0005835. https:// doi.org/10.1371/journal.pntd.0005835

Niyang, E. A, Bassene, H, Fenollar, F and Mediannikov, O. (2018). Biological Control of Mosquito-Borne Diseases: The Potential of Wolbachia-Based Interventions in an IVM Framework. Hindawi Journal of Tropical Medicine Volume 2018, Article ID 1470459, pp 15 https://doi.org/10.1155/2018/1470459.

Njabo, K.Y., Smith, T.B., and Yohannes, E. (2013). Feeding habits of culicine mosquitoes in the Cameroon lowland forests based on stable isotopes and blood meal analyses. J Para Vec Bio. 2013; 5(1):6-12.

Nkya, T. E., Akhouayri, I., Poupardin, R., Batengana, B., Mosha, F., Magesa, S., Kisinza, W., and David, J. (2014). Insecticide resistance mechanisms associated with different environments in the malaria vectorAnopheles gambiae: a case study in Tanzania. Malaria Journal; 13:28 http://www.malariajournal.com/content/13/1/28

Noori, N., Lockaby, B.G., and Kalin, L. (2015). Larval development of Culex quinquefasciatus in water with low to moderate. J Vector Ecol. 2015; 40: 208 \pm 220. https:// doi.org/10.1111/jvec.12156 PMID: 26611953 
Noutchamae, and Anumudu, C. I. (2009). Entomological indices of Anopheles gambiae Sensu lato at a rural community in south west Nigeria. J Vec Bor Dis.; 46:43-51.

Okorosobo, T., Okorosobo, F., Mwabu, G., Orem, J.N., Kirigia, J.M. (2011). Economic burden of malaria in six countries of Africa. European Journal of Business Management 3:42-62.

Ononamadu, C.J, Datit, J.T. and Imam, A.A. (2020). Insecticide Resistance Profile of Anopheles gambiae Mosquitoes: A Study of a Residential and IndustrialBreeding Sites in Kano Metropolis, Nigeria. Environmental Health Insights, 14: 1-9 sagepub.com/journalspermissions. DOI: $10.1177 / 1178630219897272$

Robert, V., Le Goff, G. and Ariey, F.A. (2002). Possible alternative method for collecting Mosquito larvae in rice fields. Malar J. 2002;1:4.

Safiyanu, M., Alhassan, A.J. and Abubakar, A.B. (2016). Detoxification enzymes activities in Deltamethrin and Bendiocarb resistant and susceptible malarial vectors (Anopheles gambiae) breeding in Bichi Agricultural and Residential sites, Kano State, Nigeria. Bayero Journal of Pure and Applied Sciences, 9(1): 142 - 149.

http://dx.doi.org/10.4314/bajopas.v9i1.22 142. ISSN 2006 - 6996

Safiyanu, M., Alhassan, A. J., Imam, A. A., and Abdullahi, H. (2017). Pyretheroids Resistance and Detoxifying Enzymes Activities of Malaria Vector (Anopheles gambiae) Breeding in Auyo Irrigation and Residential Sites, Jigawa State, Nigeria. Annual Research $\mathcal{E}$ Review in Biology; 17(2): 1-8, 2017; Article no.ARRB.36025 ISSN: 2347-565X, NLM ID: 101632869

Safiyanu, M., Alhassan, A.J., Yayo, A.M., Ibrahim, S.S., Imam, A.A. and Abdullahi. H. (2019). Detection of KDR $11014 \mathrm{f}$ mutation in pyrethroids susceptible Anopheles gambiae S.L from Ladanai, Kano state, northwest Nigeria. International Journal of Mosquito Research; 6(3): 10-15.

Soko, W., Chimbari, M. J. and Mukaratirwa, S. (2015). Insecticide Resistance in Malariatransmitting mosquitoes in Zambia: A review. Infectious Diseases of poverty, 4: 46. DOI 10.1186/s40249-015-0076-7.

Trivedi, R.K. and Goel, P.K. (1984). Chemical and Biological Methods for Water Pollution Studies. Karad: Environment Publications. Pg 56

WHO (2013). World Malaria Report. 2013. World Health Organization, Geneva, Switzerland. (http://www.who.int/malaria/publications). Accessed: January, 2014.

WHO. (2019). World malaria report 2019. Geneva: World Health Organization; 2019. Licence:CC BY- NC-SA 3.0 IGO. ISBN 978-92-4-156572-1

WHO (2021). World Health Organization, World Malaria Report (2021). https:/ / www.who.int/news-room/fact- sheet/detail/malaria. Accessed 28 April 2021

Wilke, A. B. B. and Marrelli, M. T. (2015). "Paratransgenesis: A promising new strategy for mosquito vector control," Parasites EVectors, vol. 8, no. 1, 2015. 